\title{
An evaluation of the implementation of the Science-Technology and Society (STS) concept in Science Instruction in secondary schools in Zimbabwe
}

\author{
Article by Fenton Ruparanganda \\ University of Zimbabwe, Faculty of Education \\ Email:-rprngnd@texilaconnect.com
}

\begin{abstract}
The study evaluated the implementation of the Science-Technology-Society (STS) concept during science instruction in secondary schools and the possible constraints to its implementation and the possible solutions the identified constraints.

The sample consisted of fifteen schools in Makoni District of Manicaland and involved all the Science Heads of department in the schools including five form four students per each sampled school. The total number of participants was ninety.

Data was collected using questionnaires, lesson observations and interviews. Results reflected great discrepancy between the intended and the actual implementation processes taking place in schools. The results show that the majority of the science teachers used the lecture method as opposed to the recommended child centered science teaching approaches. Half the numbers of the teachers are not well versed with the concept of STS. There is a critical shortage of science teachers. Lack of resources, staff development workshops and poor science infrastructure in schools are negatively affecting the implementation of science-technology-society education in the schools.
\end{abstract}

\section{Introduction}

Science-Technology-Society (STS) is an innovative approach to the teaching and learning of science in conjunction with modern technology. It advocates for moving away from traditional pedagogic approaches by insisting more in students understanding and doing science rather than in rote learning. Students are expected to use acquired skills to solve specific problems emanating from their societies. The approach advocates for more attention to be given to relating science to the world outside as well as to practical .This implies that STS calls for educating students so that they are able to apply science and technology (tools, knowledge, process and products) to solve problems in their environments. According to STS approaches, students should do science so as to be functional not to produce science graduates who are alien to their own society. For example, science graduates should be able to apply science and technology whilst at school, say to be productive, to grow their own food, to carry-out diseases preventive measures and to become self reliant or employed. The STS model's aim therefore lies in modeling school graduates for adaptability, for creating their own work in the informal sector or for producing school leavers equipped with not only academic skills but with a range of practical skills which make them functional citizen. STS treats education as the sole intellectual and physical tool which is responsible for preparing children for absorption into the world of work and for this reason the school science curriculum should be designed to provide "life-long education, to make children self-sufficient and productive in services deemed as needs by the society. According to Awokoya in UNESCO 1981, basic needs of African countries are food, housing, health, education, energy, transport and communication. In Zimbabwe such needs include agriculture, health, mining, environmental education, building industry and information technology education. STS education in schools should embrace the indigenous traditional skills, which in many countries can be developed and extended together with the new techniques which have to be recognized and understood. STS approaches to classroom practice recommends teaching approaches such as discovery method, problem solving, discussions, project methods, field trips and employing the philosophy of 
South American Journal of Academic Research

Special Edition May 2016

constructivism (learning from the familiar/known to the novel/complex/unknown) (UNESCO, 1993). According to Freire, (1972), pupils should not learn to be mere depositories while the teacher is the depositor; such type of education is oppressive. In other words, Freire was advocating for implementation of STS concepts to teaching and learning processes. According to MOESC, Secretary's Circular Minute No.3 of 2002, one of Zimbabwe's science education policy goals reads, "The education system expects pupils to develop skills and competencies in science and technology". Such policy was directed to be implemented in both primary and secondary level education with effect from 1 January, 2002.

\section{The purpose of this study}

The purpose of this study was to evaluate of the implementation of the Science-Technology and Society (STS) concept during Science instruction in Makoni District secondary schools and the possible constraints to its implementation and the possible solutions to address the identified constraints.

\section{Significance of the research}

Findings from this study may be used to improve the teaching and learning of science in secondary schools, provide possible strategies for improving science classroom methodologies and provide useful information to policy makers on the implementation of the STS in the teaching and learning of science. Also research findings will help science teachers on how they can design STS instruction and hence become effective and efficient science teachers. There is very little literature on STS from the Zimbabwean authors. The research findings will contribute to the much needed STS data banks in libraries. To education inspectors, findings from this study will guide inspectors on what to look for when inspecting science teachers.

\section{Literature Review}

\section{Linkage of Science-Technology-Society (STS)}

Science is refers to systematic processes which are used by humans to obtain knowledge about nature, and to an organized body of knowledge about nature. Science is a dynamic and a creative activity.

Technology involves the development and use of materials, tools, and processes for solving human problems and helping to satisfy human needs and desires. Many of the products of technology help humans accomplish tasks that would otherwise be very difficult or impossible to carry out. Although technology provides many benefits, it also produces associated costs and risks. Science often uses and requires tools and processes developed by technology, and conversely, technology often employs principles, laws, theories, and processes developed by science. Technology is also a way of knowing, and is also a process of exploration and experimentation. Technology is both a form of knowledge that uses concepts and skills from other disciplines (including science) and the application of this knowledge to meet an identified need or to solve a specific problem using materials, energy, and tools (including computers). Technological methods consist of inventing or modifying devices, structures, systems, and or processes. Science and technology are closely linked, especially through the skills of scientific inquiry, technological problem solving, and communication. So science and technology forms a cyclic reaction. This implies that science, technology and society are closely linked, especially through the skills of scientific inquiry, technological problem solving, and communication. The world as we know it today has been affected in many ways by science and technology.

\section{Reform movements in STS education}

Universal reform movement in science and technology education "gave birth' to the paradigm of the STS approaches in the late 1950s in America. The reforms were partly prompted by the interest in America in strengthening science education, after the Russians beat the USA to send the first man to space. A new vision of science learning emerged and it was 
called Science-Technology-Society approach to learning and teaching of science concepts. The new instructional strategies were far different from most traditional conceptualizations which centered on chalk-talk, teacher centered and rote learning classroom practices. The new approaches called for provision of hands-on, mind-on, and authentic learning experiences in science. This ousted the education system and curricula which had been introduced before the Second World War. Societal needs had changed hence the education system had to change also so that it was in line with new needs of society (Rosenberg, O'Donoghue and Olvitt, 2008), www.tessafrica.net, www.capeaction.org.za). STS's aimed at examining and implementing ways in which education in science and technology affected national development. It began with a consideration of the impact of science and technology on the individual, on the community and on the traditions and traditional beliefs of society. According to the STS approach, developing nation like Zimbabwe, its curriculum has to include science concepts such as biotechnology to improve yield and quality of agriculture products, study diseases and their preventive measures, job creation education, energy creation and communication in order to address the needs of Zimbabwean society. The science and technology curriculum to be offered must seek to foster individual characteristics such as curiosity, creativity and self-reliance, as well as preparing each student for life and work. The implementation of Education with Production (EWP) and tech-voc subjects by Zimbabwe after independence was done as a way of being in compliance with the STS concept. STS approaches seeks to examine the place of science and technology in education, how well science and technology serve as a driver of development in the society. The emphasis of STS is on relating learning to the immediate needs of the community in order to improve the quality of life.

\section{Changes in biology through implementation of STS education}

Trends brought in biology through implementation of STS on biology are concerned with the tools that have been developed to new levels of performance. These include the electron microscope, the ultracentrifuge, $\mathrm{X}$-ray, crystallography and nuclear magnetic resonance. Rapid developments are currently being made in areas like cytology (e.g. concept of cell-surface receptors); in immunology, and in neuroscience, genetic engineering and in gene therapy just to mention a few areas. In neuroscience, for example, the study of cell-surface receptors has revealed the presence of hormone-like transmitters in the brain. Applications of biotechnology concepts to agriculture have increased agriculture yields drastically. Genetic engineering has managed to control many diseases such as sugar diabetes and has resulted in production of hybrid organisms and artificial creation of organisms (transgenic organisms) of which are of great beneficial to man. In brief, application of STS approaches in biology and other science subjects has made it possible for the human-race to live healthier, happier and more comfortable and interesting lives than those who lived in the past (Osborne, 1983).

\section{Planned actions in Africa for facilitating STS concepts}

Soon after independence, all African States regarded STS education as their first priority area to develop. Education has been treated as a major instrument for the social, economic, cultural and political modernization of the developing countries. The Conference of African States on the Development of Education in Africa held in Addis Ababa in 1961 made certain recommendations and set up certain education targets. One of the set objectives was a drive to quantitative scientific and technical education literacy.

With regards to science teaching approaches, the Lagos Conference recommended the adaptation of new pedagogical approaches. The recommendations included the introduction of science teaching in the early years of schooling, the use of more realistic science methods of practical and experimental work, and the production of new relevant teaching and learning materials which are suited to local conditions. 
South American Journal of Academic Research

Special Edition May 2016

\section{Trends of STS in Zimbabwe}

In the context of science and technology education, the Harare Declaration noted that 'technical and vocational' education has not been sufficiently developed and that the attention given to agricultural education was found to bear no relation to the economic structure of the African countries. The teaching of science and technology was found to be introduced too late in school curricula and is seldom provided for adults in the context of out of school education. The resolution taken was to "develop and renovate science and technology teaching at all levels and have activities designed to popularize science among the general public, in order to promote full utilization of modern scientific and technological knowledge in development, to stimulate an interest in a scientific career and to increase the number of pupil students opting for work in scientific fields” (UNESCO, 1982).

\section{Government and science-technology-society education in Zimbabwe}

In response to provision of the infrastructure conducive to delivery of science education and technology, the Zimbabwean government embarked on a program to increase science Higher learning education institutions. Institutions such Bindura University of Science and Technology (BUSE), Higher Institute of Technology (HIT), Chinhoyi University of Technology (CUT), National University of Science and Technology (NUST), the conversion of Belvedere Teachers' College (BTT) into Belvedere teacher's Technical College) and the increase in poly technology colleges was a devotion by the government to ensure the provision of science education and technology to the society. All this was in line with what the Addis Ababa, the Tunis, the Dakar and the Harare declarations called for.

\section{Benefits of STS education to society}

As science for All Americans points out, good STS education help students to develop the understandings and habits of mind they need to become compassionate human beings able to think for themselves and to face life head on. STS education should equip them also to participate thoughtfully with fellow citizens in building and protecting a society that is open, decent, and vital. In short, science and technology have made it possible for people to live healthier, happier and much more comfortable and interesting lives than was previously possible. Scientific and technological knowledge has contributed, perhaps more than any other factor to the economic growth of both developed and developing countries.

The more science-literate citizens are, the stronger their society can be. Specifically, the lessons and skills science gives us can have repercussions that help make more responsible citizens, a strong economy, a healthier environment, and brighter future for everyone. The dominance of technology in society today reaffirms the modern philosophical orientations and necessitates that today's students achieve a level of scientific/technological literacy that will help them deal with science related societal issues for the improvement of their own lives and the advancement of the society at large. To achieve this specific recommendations have been formulated for instruction related to science-technology-society education.

\section{Methodology}

This study was to evaluate the implementation of the Science-Technology-Society (STS) concept during science instruction in secondary schools and the possible constraints to its implementation and the possible solutions the identified constraints.

A questionnaire for teachers to assess the teachers' knowledge about the STS, constraints to its implementation and the possible solutions the identified constraints was used. Another questionnaire was used to assess the Science Head of Department's knowledge about the importance of the teaching methods and how she or he monitors the teaching and learning STS. Lesson observations were also done in order to evaluate the implementation of STS in the teaching and learning of science. 


\section{Results}

Table 1: Teachers' knowledge about STS in the teaching and learning of science

\begin{tabular}{|l|l|l|}
\hline & Frequency & \% \\
\hline Knowledgeable & 3 & 20 \\
\hline Not Knowledgeable & 12 & 80 \\
\hline
\end{tabular}

Table 2: Factors influencing the implementation of STS concept

\begin{tabular}{|l|l|l|}
\hline Factors Identified & Frequency & Percentage \\
\hline No guidelines on STS & 9 & 60 \\
\hline Inadequate resources & 13 & 87 \\
\hline Poor science infrastructure & 7 & 47 \\
\hline Poor deployment of available resources & 3 & 20 \\
\hline Large classes & 15 & 100 \\
\hline Teachers computer illiterate & 5 & 33 \\
\hline
\end{tabular}

Table 3: Prevalence of science teaching methodologies

\begin{tabular}{|l|l|}
\hline Teaching method & Teachers using this method during lesson observations \\
\hline Lecture method & 13 \\
\hline Problem solving method & 1 \\
\hline Project method & 0 \\
\hline Computer simulation & 0 \\
\hline Practical demonstrations & 1 \\
\hline Educational field trips & 0 \\
\hline
\end{tabular}

Table 4: Availability of resource in schools for efficient science teaching

\begin{tabular}{|l|l|l|l|l|l|}
\hline & None & Inadequate & Adequate & In Excess & Total \\
\hline Laboratory & 60 & 10 & 5 & 0 & 75 \\
\hline Science & 50 & 15 & 10 & 0 & 75 \\
\hline Science & 50 & 15 & 10 & 0 & 75 \\
\hline Computers & 65 & 10 & 0 & 0 & 75 \\
\hline Text books & 0 & 55 & 15 & 5 & 75 \\
\hline
\end{tabular}

\section{Discussions and conclusions:}

According to teachers implementation of STS in schools is being hindered by large classes. In such a situation teachers will concentrate on completing the syllabus so that they meet the immediate need of the pupil which is passing examinations. Inadequate resources contributed to poor implementation of the concept. The way students acquires knowledge during learning experience at school depend on the modes of teaching being applied by their teachers or mentors. Poor teaching methods are being employed which don't promote STS. Science lessons require hands-on-approaches. The lecture method was the commonly used teaching methods. STS methodologies advocate for use of teaching methodologies such as project method, computer simulation, educational trip which stimulated critical thinking and problem solving in students. Poor infrastructure such as laboratories and inadequate learning materials are hindering the implementation of STS concepts in the sampled schools. Teachers are not well versed with the concept of STS. Eighty percent of the teachers could not give a correct definition of the STS concept.

\section{Research recommendations}

The study makes the following recommendations:

The concept of STS should be given more attention in training science teachers in all teachers' colleges. The use of project method as a teaching approach should include assessment of pupils' projects as what is being done in subjects like Building Studies and Agriculture. It is 
South American Journal of Academic Research

Special Edition May 2016

hoped that this will encourage teachers to implement the approach Guide lines on the implementation of STS approaches to learning must be made available to science teachers. Staff development workshops on STS approaches should be carried out at all levels (school, zonal, district) as refreshers to teachers who may not have a chance to be trained on STS in the past.

School Heads must be trained on implementation of STS approaches so that they can monitor efficiently and effectively the implementation of STS concepts in their schools. Education administrators must ways of improving science resources in the education system and finding possible ways of luring science teachers and reducing teacher pupil ratio for the science subject.

\section{References}

[1] Achinstein, B. \& Villar, A. (2002). Politics of the Mentoring Process for Novices: Negotiating Professional Relationships and New Teacher Learning. Paper presented at the American Educational Research Association in New Orleans. P.A.P.E. CEP, Grahamstown. Rhodes University.

[2] Aikenhead, G. (2005). Science for everyday life: Evidence-based practice. New York:

[3] Aikenhead, G. and Solomon, J. (1994).Eds. STS Education: International Perspective on Reform. New York. Teachers College Press.

[4] Ary, D., Jacobs, L. C. and Razavieh, A. (1972). Introduction to Research in Education. London. Rinehart and Winston.

[5] Ausubel, D.P. (1968). Educational Psychology: A Cognitive View. Holt. Rinehart and Winston.

[6] Barker, R. (1990). Philosophies of Education: An Introductory Course. Harare. College Press.

[7] Bell, J. (1993). 2nd. Doing your research Project: A Guide for first-time researchers in Education Science. Buckingham. Open University Press.

[8] Borg, W. R. and Gall, M. D. (1989). Education Research: An Introduction. London. Longman.

[9] Business Herald of 28 / 12 /89. Harare.

[10] Business Herald of 28/12/89.

[11] Bybee, R. (1993b). Reforming Science Education: Social perspectives and Personal Reflections. Washington DC. Teacher's College Press.

[12] Chemistry, Vol. 19, Iss. 2 (2010)

[13] Chetsanga, C. J. (1994). Genetic diversity of Hepatitis B virus isolation in Zimbabwe. Journal. Med.vol.42:73-78.

[14] Chikwamba, R.K.. (1995). State of the art of Biotechnology Research in Zimbabwe.

[15] Circular Minute No. 2 of 2001. Zimbabwe. MOESC).

[16] Cohen, L. and Manion, L. (1980). Research Methods in Education. London. Croom Helm Ltd.

[17] David-de, V. (2002). 5th Ed. Surveys in Social Research. London. Routledge.

[18] Descombe, M. (1998). A Good Research Guide for small scale social Projects. Philadelphia. Open University Press.

[19] Duschl, R. (2008). Science education in three-part harmony: Balancing conceptual,

[20] Engestrom, Y. (1999). Innovative learning in work teams: Analysing cycles of knowledge creation in Practice. In Y. Engestrom, R. Miettinen \& R.L.Punamaki (eds). Perspectives on Activity Theory. Cambridge. Cambridge University Press.

[21] Fensham, P. (2007). Policy issues for science education. Discussion paper prepared for epistemic, and social learning goals. Review of Research in Education, 32, 268-291.

[22] Fowler, F. J. (2002). 3rd Ed. Survey Research Methods. Thousand Oaks. Ca. Sage.

[23] Fraenkel, J. R. and Wallen, N. E. (1990). How to Design and Evaluate Research in Education. New York. McGraw-Hill Publishing Company.

[24] Freire, P. (1972). Pedagogy of the Oppressed. New York. Penguin Books Ltd

[25] Gagne, R.M. (1977). The Conditions of Learning. Holt. Rinehart and Winston.

[26] Gatawa, B.S.M. (1990). The Politics of the School Curriculum: An Introduction.

[27] Gay, L. R. (1979). Educational Evaluation and Measurement: Competencies for Analysis and Applicational Evaluation and Measurement: Toronto. Charles, E. Merrill.

[28] Geddis, A.N. (1993).Transforming Subject Matter Knowledge: The Role of Pedagogical Content Knowledge in 
Learning to Reflect on Teaching. Intern. J. Sci. Educ. 15,673-683.

[29] Guilford, J. P. (1995). 4th Ed. Fundamental Statistics in Psychology and Education. New York. Education. [30] Hammenet, 23 - 27 April 1999, Fifth General Conference of the African Academy of Science (Tunisia Declaration).

[31] http://echo.gmu.edu/center/

[32] http://mwl.merriam-webster.com/dictionary/technology

[33] http://science.howstuffworks.com/

[34] http://www.belugaschoolforlife.com/

[35] http://www.fundacionypf.org.or/indexn.html.

[36]

http:www.nap.edu/readingroom/books/nses/html/action.html/action.html

http://www.project2061.org/tools/sfaaol/Intr.htm,

[37] http://www.schoolforliife.org/en/index.html

[38] http://www.usak.ca/education/people/aikenhead/cvshort.htm. http://www.adre.edu.av./94pop/peacl.94257.txt.

[39] Jegede, Olugbemiro J., Peter A. Okebukola, and Gabriel A. Ajewole. (1991). "Computers and the Learning of Biological Concepts: Attitudes and Achievements of Nigerian Students". Science Education 75 (6): 701-06.

[40] Jokomo, E., Moyo, W.F., Ndowora, M.C., Mukwekwezeke, S.M., Madhowi, A.M., Ranganai,G.P., Hosking, B. and Groombridge, (1990) D.B. Handbook For Science Teaching. Harare. The Standard Control Unit of the Ministry of Education, Sport, Arts and Culture.

[41] Jones, M.G., Rua, M.J. \& Carter, G. (1998). Science Teachers’ Conceptual Growth within Vygotsky’ Zone of Proximal Development. J. Res. Sci. Teaching 35, 967 - 985.

[42] Kelly, G. A. (1991). The Psychology of Personal Constructs: Vol. One. A Theory of Personality. London. Routledge.

[43] Leedy, P. D. (1985). Practical Research Planning and Design. New York. MacMillan Publishing Company.

[44] Machinga, G, Report presented to the cabinet in March 2000 on the Nziramasanga Commission findings.

[45] MODULE 6: New Technologies in Teaching and Learning in Higher Education. UNESCO-AFRICA.

[46] MOESC. Secretary’s Circular Minute NO. 2 of 2001.

[47] Nkrumah, K. 1964. Consciencism. London. Heineman.

[48] Nwaboku, N.C. (1997). New information technologies in education and new roles for potential teachers. UNESCO-AFRICA 15/15, 30-37

[49] Okanlawon, A.E. (2010). Constructing a framework for Teaching reaction Stoichiometry using Pedagogical Content Knowledge. Nigeria. Department of Science, Technology and Mathematics Education.

[50] Osborne, D.G. (1983). A paper prepared for inclusion in Reflections on the Future Developments of Education. Paris. UNESCO.

[51] Parawira and Khosa. (2009). Scientific Research and Essay. Vol.(4).(9), pp. 825-841, September, 2009.

[52] Richards, L. (2008). Handling Qualitative Data. A Practical Guide. London. Sage Publications.

[53] Rosenberg, E., O’Donoghue, R. and Olvitt, L.(2008). Methods and Processes to support Change-Oriented Learning. Grahamstown. C.A.P.E. CEP, Rhodes University.

[54] Science-Technology-Society in the Science Curriculum. ERIC/SMEAC Special Digest No. 2.

[55] Sidhu, K. S. (1984). Methodology of Research in Education. New Delhi. Sterling Publishers.

[56] Solomon, J. and Aikenhead, G. (1994). STS Education: International Perspectives on reforms. New York. Teacher's College Press.

[57] Strotman cited in Teachers Forum, 1990. Vol 18: NO.3.

[58] Sutton, F. X. (1964). Africa's Educational Needs and Opportunities. Addis Ababa Conference, “man and Africa”.

[59] Teacher’s Forum. October 1989.

[60] The Herald, 4 October 2010

[61] The Lagos Plan of Action of 1980 (Science for the twenty-first century: A new Commitment.

[62] Tuckman, B. W. (1994). 4th Ed. Conducting Educational Research. New York. Harcourt Brace College Publishers.

[63] UNESCO (1993). Science \& Technology Education and National Development. France. UNESCO.

[64] UNESCO, (1982). Harare Declation. Africa. Unesco.

[65] Van Dalen, D. B. (1979). Understanding Educational Research: An Introduction. New York. McGraw-Hill Book Company. 
South American Journal of Academic Research

Special Edition May 2016

[66] White, B. (2000). Dissertation Skills for Business and Management Students. London. Continuum.

[67] World Conference on Science and Technology. Perth, Australia, 8-12 July.

[68] World Conference on Science. Budapest. Hungary. 26 June - 1 July 1999.

[69] www.capeaction.org.za

[70] www.ru.ac.za

[71] www.tessafrica.net.

[72] Yager, R.E. (1996). Science/technology/society as reform in Science, technology and society: Albany, NY:

State University of New York Press.

[73] ZIMSEC. (1998) Biological Sciences: Report on the June 1998 Examinations. Mt Pleasant. Zimsec.

[74] ZIMSEC. Syllabi (5006, 5008 and 5009), Harare. ZIMSEC. 